\title{
Fine structure of mushroom bodies and the brain in Sthenelais boa (Phyllodocida, Annelida)
}

\author{
Patrick Beckers $^{1}$ (1) $\cdot$ Carla Pein $^{1} \cdot$ Thomas Bartolomaeus $^{1}$
}

Received: 11 August 2021 / Revised: 29 October 2021 / Accepted: 13 November 2021 / Published online: 2 December 2021

(c) The Author(s) 2021, corrected publication 2021

\begin{abstract}
Mushroom bodies are known from annelids and arthropods and were formerly assumed to argue for a close relationship of these two taxa. Since molecular phylogenies univocally show that both taxa belong to two different clades in the bilaterian tree, similarity must either result from convergent evolution or from transformation of an ancestral mushroom body. Any morphological differences in the ultrastructure and composition of mushroom bodies could thus indicate convergent evolution that results from similar functional constraints. We here study the ultrastructure of the mushroom bodies, the glomerular neuropil, glia-cells and the general anatomy of the nervous system in Sthenelais boa. The neuropil of the mushroom bodies is composed of densely packed, small diameter neurites that lack individual or clusterwise glia enwrapping. Neurites of other regions of the brain are much more prominent, are enwrapped by glia-cell processes and thus can be discriminated from the neuropil of the mushroom bodies. The same applies to the respective neuronal somata. The glomerular neuropil of insects and annelids is a region of higher synaptic activity that result in a spheroid appearance of these structures. However, while these structures are sharply delimited from the surrounding neuropil of the brain by glia enwrapping in insects, this is not the case in Sthenelais boa. Although superficially similar, there are anatomical differences in the arrangement of glia-cells in the mushroom bodies and the glomerular neuropil between insects and annelids. Hence, we suppose that the observed differences rather evolved convergently to solve similar functional constrains than by transforming an ancestral mushroom body design.
\end{abstract}

Keywords Annelida $\cdot$ Nervous system $\cdot$ Ultrastructure $\cdot$ Mushroom bodies · Glomerular neuropil · Glia cells

\section{Introduction}

Mushroom bodies are paired brain centers described for arthropods and annelids (Strausfeld et al. 2009; Wolff and Strausfeld 2015). Already mentioned for Arthropods in 1850 (Dujardin 1850), similar structures were described nearly 40 years later in species of the annelid taxon Polynoidae (Haller 1889). Due to their similar anatomy, these higher brain centers were historically supposed to be one character, among others, to substantiate annelid and arthropod

Patrick Beckers

pbeckers@evolution.uni-bonn.de

Carla Pein

carla.pein@gmx.de

Thomas Bartolomaeus

tbartolomaeus@evolution.uni-bonn.de

1 Institute of Evolutionary Biology and Zooecology, University of Bonn, 53121 Bonn, Germany relationship, formerly united as Articulata (Hamaker 1898; Turner 1899; Ax 2000).

Mushroom bodies consist of parallel arranged nerve fibers or neurites (called the foot or pedunculus of the mushroom body) which originate in small nerve cell somata and terminate in the brain. Due to the high number of neurons the somata form a hemispherical "helmet" of staggered perikarya that reminds on the hood of a mushroom. In insects, these cells are called Kenyon-cells, in Annelida globulicells. Branches of the pedunculus, called lobes, often merge medially with the ones on the corresponding side (Bullock and Horridge 1965; Strausfeld et al. 1998). Mushroom bodies are supposed to be association areas or higher brain regions which are involved in olfactory perception, memory and learning in insects (Strausfeld et al. 1998; Wolff and Strausfeld 2015). Detailed studies on the function of mushroom bodies of polychaetes are lacking, but recently their relation to chemosensory function was shown in the annelid Platynereis dumerilii (Audouin and Milne Edwards 1833) (Chartier et al. 2018). 
Often spherical structures are found at the base of the neuropil of the pedunculus. These show a stronger staining in histology and are called glomerular neuropil (Bullock and Horridge 1965; Golding 1992; Beckers and Tilic 2021). In polychaetes these structures are supposed to be regions of higher synaptic areas (Bullock and Horridge 1965; Golding 1992; Heuer et al. 2010; Purschke 2015).

Glia-cells are important non-neuronal components of the nervous system with a variety of functions and specific cell types involved in repairing and pathway processes in the nervous system (Radojcic and Pentreath 1979). They are also important to pattern the nervous system (Helm et al. 2017, 2018; Beckers et al. 2019a, b). In addition, glia cells may also surround the whole nervous system and serve as a protective barrier (Baskin 1971a, b).

While ultrastructural investigations on the general anatomy of the central nervous system and glia cells as well as mushroom bodies of polychaetes are scarce (Golding 1992), mushroom body anatomy has intensely been investigated in arthropods and especially insects on a histological and immunohistochemical level. However, only a few ultrastructural investigations on the general anatomy were conducted (Trujillo-Cenóz and Melamed 1962; Landolt 1965; Landolt and Ris 1966; Mancini and Frontali 1967; Ganeshina and Menzel 2001; Wolff and Strausfeld 2015). In order to fill this gap of knowledge we studied the mushroom bodies in Sthenelais boa (Johnston 1833) (Sigalionidae), a vagile, carnivorous and presumably predatory species. Sigalionidae are known for their clearly identifiable, prominent mushroom bodies that originate laterally in the brain (Hanström 1927; Bullock and Horridge 1965; Heuer et al. 2010; Purschke 2015).

Since mushroom bodies are supposed to be involved in the processing of sensory input, we also studied their connection to important sensory structures, such as the eyes, the palps and the nuchal organs. While eyes perceive optical input, palps and nuchal organs are supposed to be involved in the uptake of chemical cues from the environment (Purschke 2005). To visualize the brain anatomy we used $\mu \mathrm{CT}$, classical Azan staining of cross and horizontal sections and Palmgren's silver impregnation as well as TEM to investigate the cellular components of mushroom bodies, of the glomerular neuropil and the glia.

\section{Materials and methods}

Adult specimen of Sthenelais boa (Johnston 1833) (Fig. 1A, B) were collected during low tide in Roscoff in April 2016 in fine-grained sediment of Zostera medows. Animals were kept in petri-dishes in the fridge prior to fixation.

\section{Paraffin-histology}

Animals were relaxed in a $7 \% \mathrm{MgCl}_{2}$ solution mixed with seawater $1: 1$ and then fixed in a modified Bouin-Dubosq-Brasil solution (0.8\% picric acid, $7 \%$ formalin and 2\% acetic acid in 56\% ethanol) for $6 \mathrm{~h}$, dehydrated in an ethanol series, followed by ethanol-butanol and butanol and preincubated in Histoplast (Thermo Scientific, Dreieich, Germany) at $60{ }^{\circ} \mathrm{C}$. After 3 days with several medium changes they were finally embedded in Histoplast (ThermoFischer, Germany). Serial sections of $5 \mu$ m thickness were performed using a microtome (Autocut 2050, Reichert-Jung, Leica, Wetzlar) and transferred to glass slides coated with albumen-glycerin (Beckers et al. 2021).

One specimen of Sthenelais boa was sectioned in horizontal, two in cross sections and were stained with Azan. One specimen of $S$. boa was stained with Palmgren's silver impregnation after cross sectioning (Palmgren 1948). Scales were removed prior to sectioning to prevent cutting artifacts.

\section{$\mu C T$}

Specimens used for $\mu \mathrm{CT}$ investigations were fixed overnight using Bouin-Dubosque-Brasil fluid. Animals were washed in $70 \%$ Ethanol and stained with $0.3 \%$ PTA (phosphotungstic acid) in $70 \%$ Ethanol for 1 week. Afterwards, animals were scanned with a $\mu \mathrm{CT}$ (Skyscan 1272, Burker, Germany) at $600 \mathrm{~nm}$ resolution. Image stacks were further processed using Fiji (version 1.52 h) (Schindelin et al. 2012).

\section{Semi-thin sectioning and TEM}

Anterior parts of Sthenelais boa were fixed in a 2.5\% glutaraldehyde solution buffered in $0.05 \mathrm{M}$ phosphate buffer $0.3 \mathrm{M}$ saline $(\mathrm{pH} 7.2)$ at $4{ }^{\circ} \mathrm{C}$ for $2 \mathrm{~h}$ and kept in the same buffer. The specimens were postfixed in $1 \% \mathrm{OsO} 4$ buffered in $0.05 \mathrm{M}$ phosphate $0.3 \mathrm{M}$ saline at $4{ }^{\circ} \mathrm{C}$ for $1 \mathrm{~h}$, subsequently dehydrated in an ascending acetone series followed by propylene oxide and embedded in Araldite. Semi-thin and ultra-thin sections of $1 \mu \mathrm{m}$ and $70 \mathrm{~nm}$ thickness, respectively, were cut on a LEICA UC6 ultramicrotome. Semi-thin sections were kept on glass slides and stained with Toluidine blue, while ultra-thin sections were placed on formvar coated, copper single slot grids $(1 \times 2 \mathrm{~mm})$ and automatically stained with uranyl acetate and lead citrate (QG-3100, Boeckler Instruments). Ultrathin sections were analyzed with a ZEISS EM10CR transmission electron microscope and documented on phosphor imaging plates (DITABIS) while semi-thin sections were documented using a light microscope (BX-51, Olympus). 

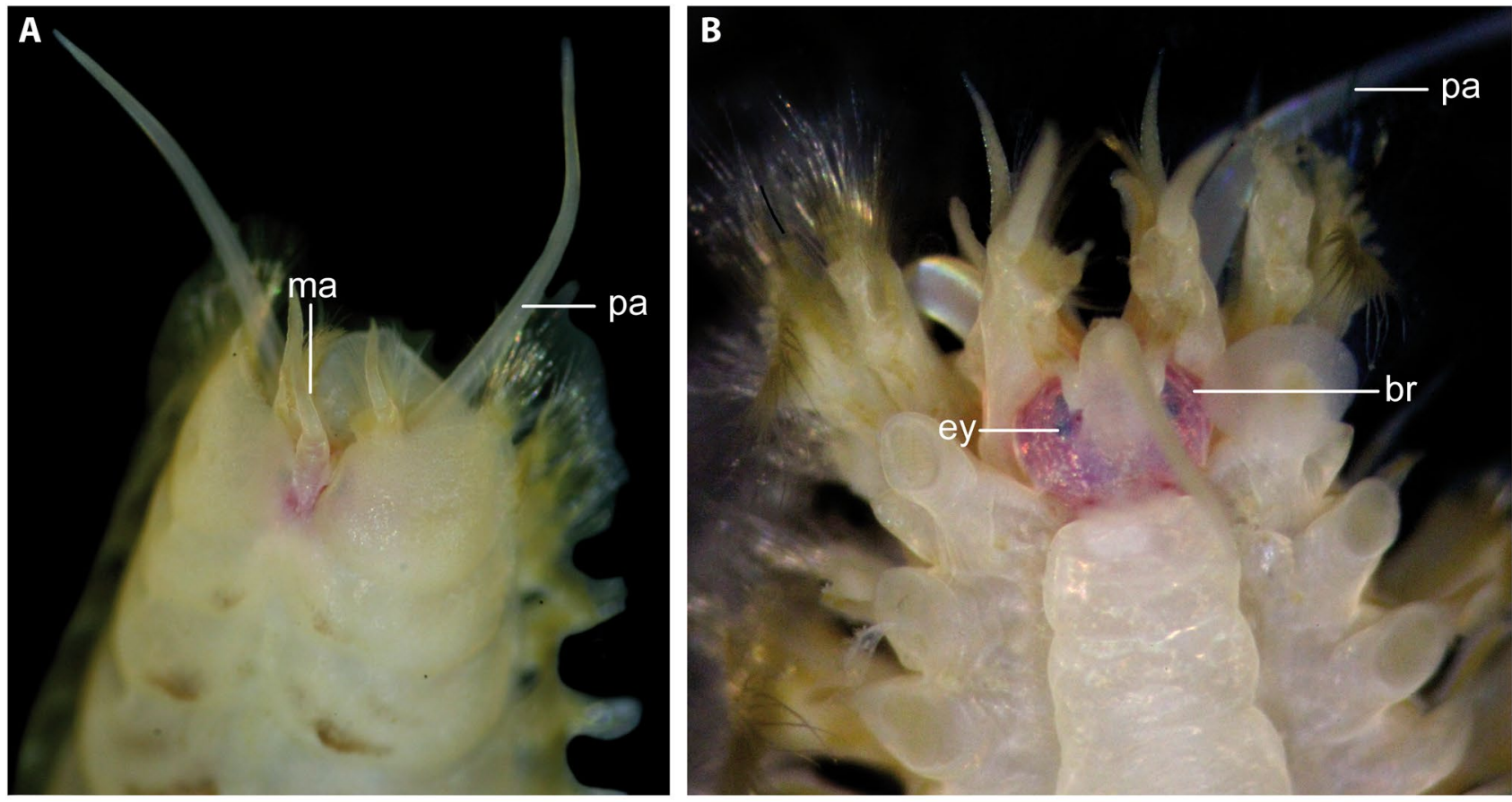

C

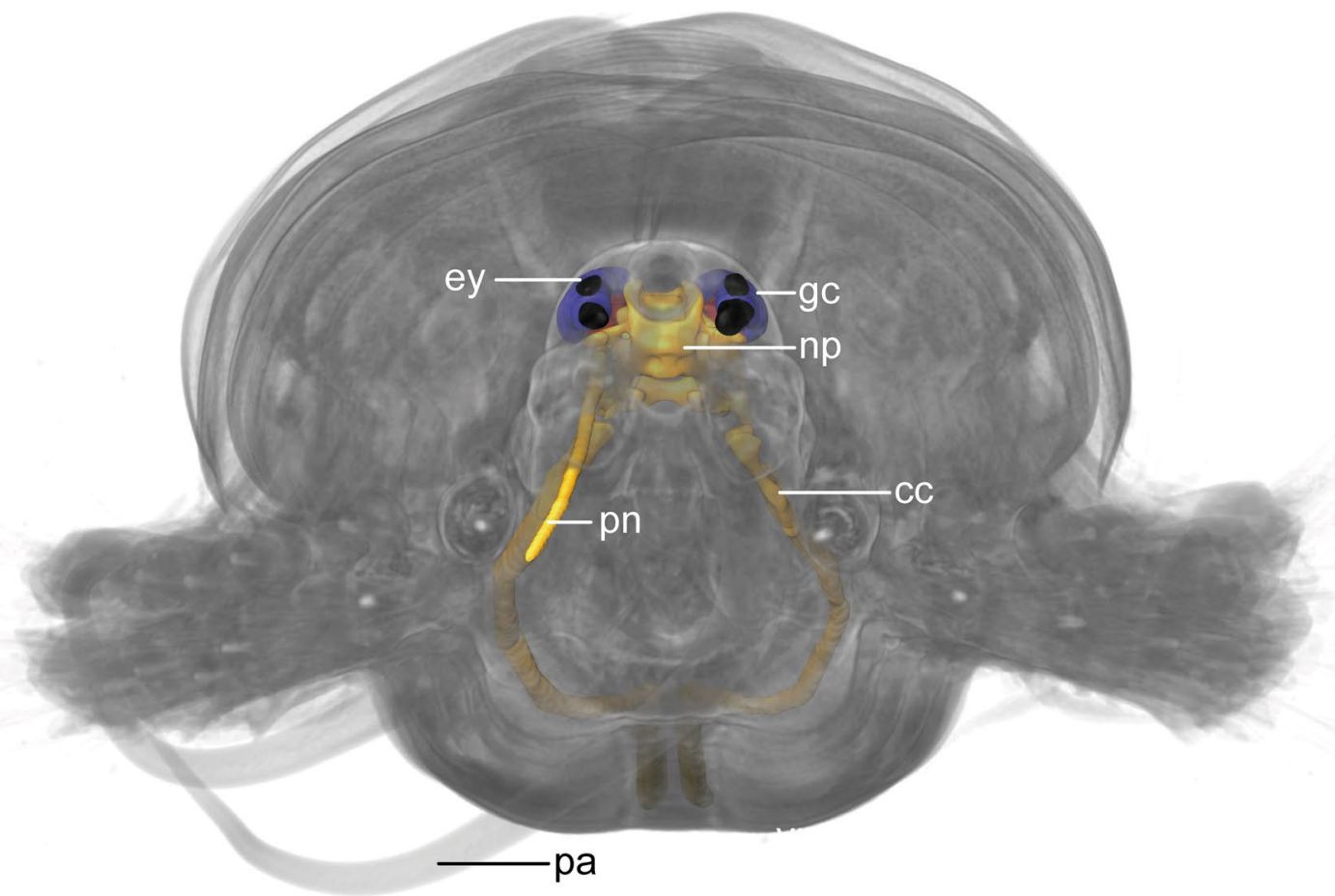

Fig. 1 Living specimen and volume, surface rendering $\mu \mathrm{CT}$. A Sthenelais boa natural morphology. ma median antenna; pa palp. B Sthenelais boa scales removed. The brain $(b r)$ is colored in red. ey eye; $p a$ palp. $\mathbf{C} \mu \mathrm{CT}$ volume rendering and $3 \mathrm{D}$-reconstruction of mushroom bodies and nervous system. $c c$ : circumesophageal connectives; ey eye; $g c$ globuli-cells; $n p$ neuropil of the brain; $v n s$ ventral nervous system 
A

A

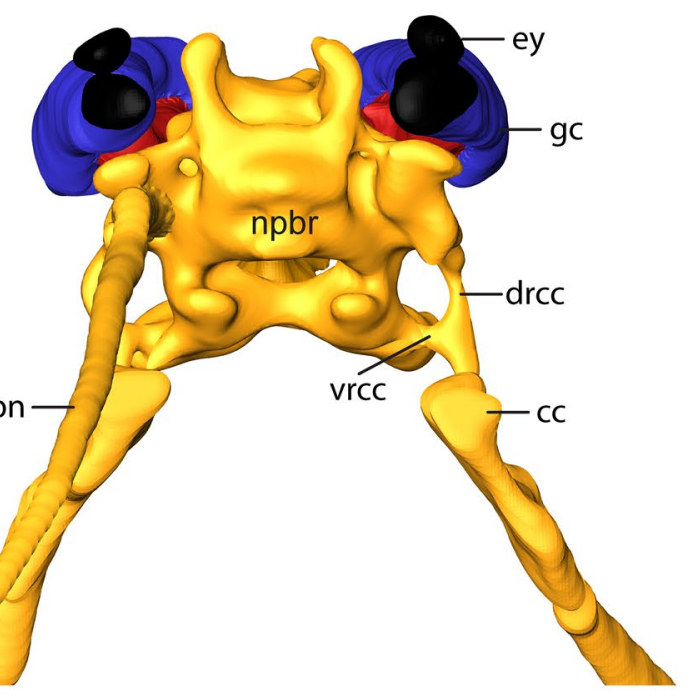

B

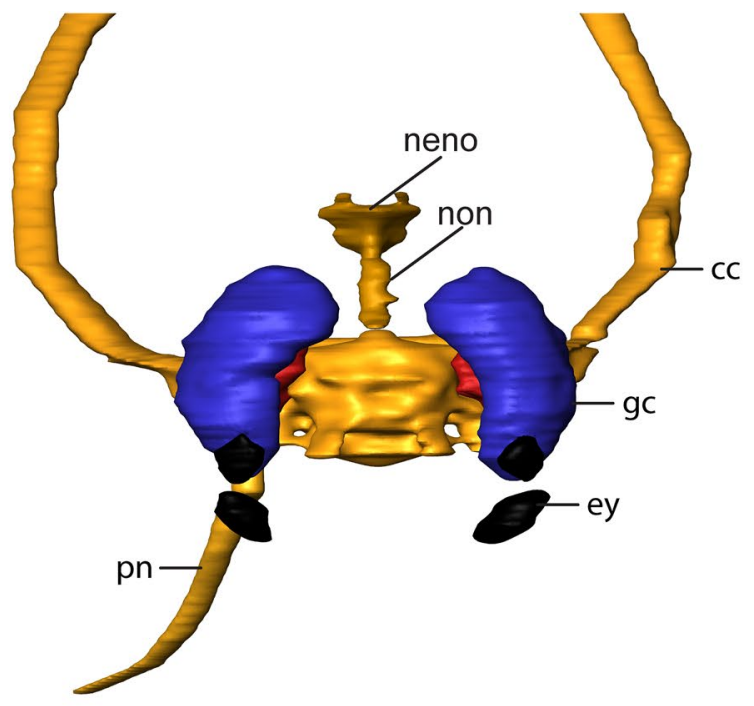

C
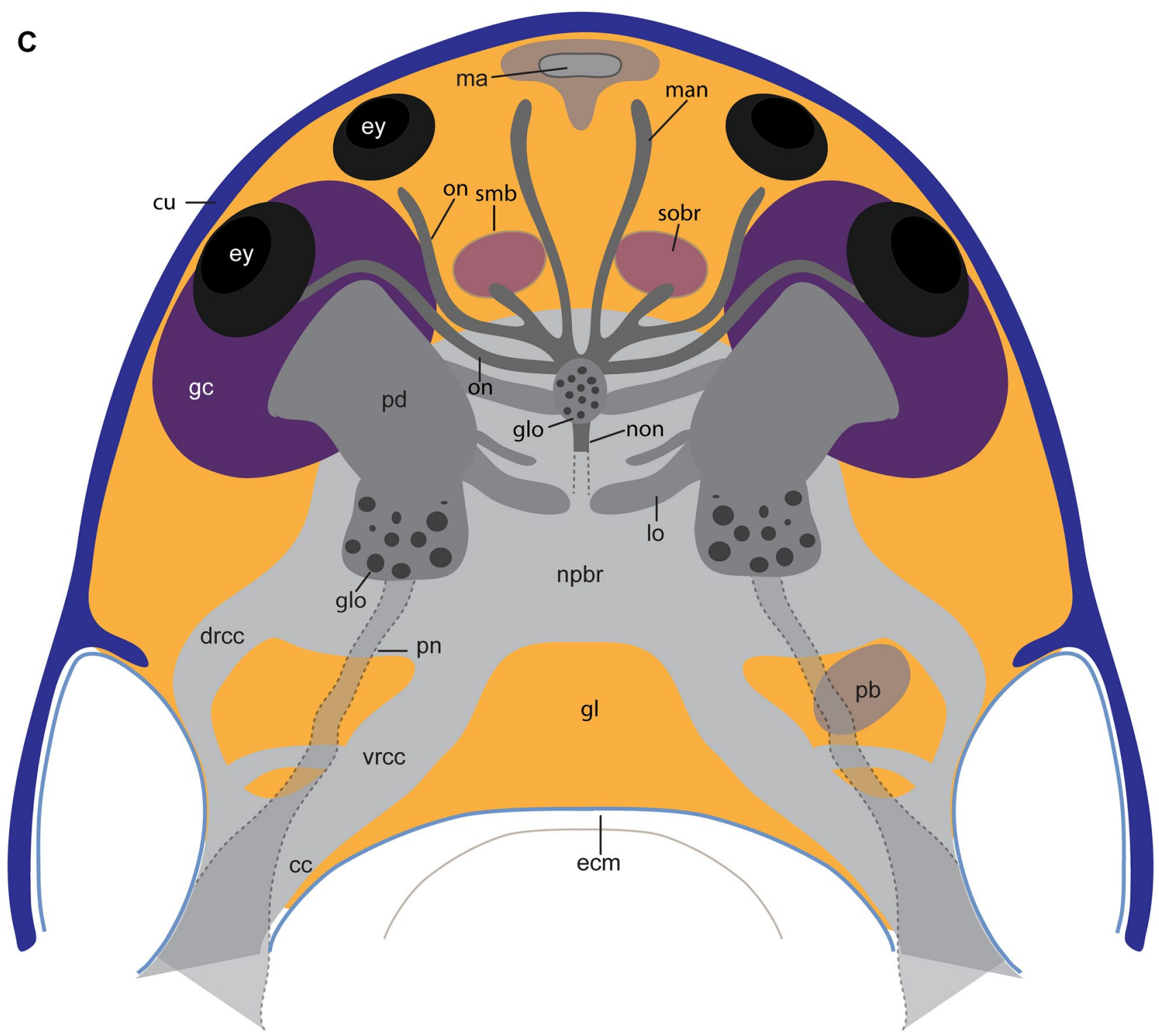
4Fig. 2 3D reconstructions and schematic drawing of elements of the brain in Sthenelais boa. A Frontal view. ey eye; cc circumesophageal connective, $d r c c$ dorsal root of cc; $g c$ globuli-cells; $n p b r$ neuropil of brain; vrcc ventral root of cc. B Dorsal view. ey eye; $c c$ circumesophageal connective; $g c$ globuli cells; neno neurites of the sensory cells of the nuchal organ; non nuchal organ nerve. C $c c$ circumesophageal connective; $\mathrm{cu}$ cuticle; $d r c c$ dorsal root of cc; ecm extracellular matrix; ey eye; $g c$ globuli-cells; $g l$ glia cell layer; glo glomerular neuropil; lo lobe of mushroom body; $m a$ base of median antenna; man median antenna nerve; non nuchal organ nerve; $n p b r$ neuropil of brain; on optical nerve; $p b$ base of palp; $p n$ palp nerve; $s m b$ small mushroom bodies; sobr somata of the brain; vrcc ventral root of cc

\section{Analysis and 3D reconstruction}

Living specimens were photographed with a Canon 600D Camera mounted on a Zeiss-Stemi 2000. Serial paraffin and semithin sections were analyzed with an Olympus microscope (BX-51) and photographed with an Olympus camera (Olympus cc12) equipped with the dot slide system (2.2 Olympus, Hamburg) and aligned using Imod (Kremer et al. 1996) and Imod align (http://www.qterra.de/biowelt/3drekon/guides/imod_first_aid.pdf). $3 \mathrm{D}$-reconstruction of virtual sections were performed using Fiji (version 1.52 h) (Schindelin et al. 2012)/trakem (Cardona et al. 2012) and Amira (5.0) (Thermo Fisher). $3 \mathrm{D}$-reconstructions and volume renderings of the $\mu \mathrm{CT}$ scans were performed using Amira 5.0 (Thermo Fisher).

\section{Data repository and voucher material}

The voucher material of Sthenelais boa is deposited at the Institute of Evolutionary Biology and Zooecology of the University of Bonn. For data transparency, all aligned serial sections, as well as $\mu \mathrm{Ct}$-scans are freely available in MorphDbase: www.morphdbase.de (Grobe and Voigt 2008, 2014).

$\mu$ CT part1: www.morphdbase.de/?P_Beckers_20200 310-M-115.1.

$\mu$ CT part2: www.morphdbase.de/?P_Beckers_20200 310-M-114.1.

Azan, cross-sections: www.morphdbase.de/?P_Becke rs_20200310-M-108.1.

Azan, horizontal sections: www.morphdbase.de/?P Beckers_20200310-M-110.1.

Palmgrens silver, cross: www.morphdbase.de/?P_ Beckers_20200310-M-109.1.

\section{Results}

\section{General anatomy}

The brain can be identified in the living animal by its red coloration (Fig. 1A, B); it is located inside the prostomium but intraepidermal (Figs. 1C, 2C, 3, 4A, $\mathrm{B}, 5 \mathrm{~A}, \mathrm{~B})$. The brain is composed of a central neuropil, which is embedded in a massive layer of glia-cell processes and somata showing an orange coloration in Azan staining (Figs. 2, 3, 4). Different clusters of neuronal somata are located in between the glia cell layers (Fig. 3B, 5A). The circumesophageal connectives originate in the posterior ventral part of the brain and have three roots (Figs. 2, 3C, 4C, 5B). The neuropils of these roots encircle the base of the palps and merge in a ganglion (Holmgren's ganglion) which is also surrounded by a prominent glia cell layer (Fig. 3C, D). The circumesophageal connectives surround the mouth and merge ventral to the esophagus in the subesophageal ganglion (Fig. 1C). From here on the ladder-like ganglionic ventral nervous system arises and extends along the whole lengths of the body (Fig. 1C). Mushroom bodies originate in the median part of the brain. Towards the inner part of the brain, the pedunculus splits into several lobes that merge with the ones on the corresponding side (Figs. 2, 3B, 4A, B, 5B, C, 7A). A glomerular neuropil is located at the base of the pedunculus close to the neuropil of the brain and on the merging points of several brain commissures and lobes of the mushroom bodies (Fig. 2C). The so-called small mushroom bodies are located in the median dorsal part of the brain (Figs. 2C, 3B1, 5B).

\section{Fine structure of the brain}

Inside the brain neuropil, which is composed of densely interwoven neurites, different tracts or neurite bundlescan be discriminated. The neurites of these tracts are arranged differentially than the surrounding neuropil. The neurites of the nuchal organ nerves for instance run parallel to the body axis and appear as dots in cross section (Figs. 3C, 8C). Others, such as the neurites of the optical tract, run rectangular to the body axis and appear as bands in cross section (Fig. 5A, B). Neurites of the brain are lesser uniform in diameter than those of the mushroom body (Figs. 4B, 6D). In addition, glia-cell processes are associated with the neurites of the brain. Radial glia, however, may occasionally cross the pedunculus of the mushroom body (Fig. 6D).

Different types of neuronal somata are discernible in the brain. Neuronal somata are clustered and located peripheral to the brain neuropil (Fig. 3B). Their somata and nuclei are enlarged compared to the somata of the globuli cells of the mushroom body (Figs. 3A, 4A-C, 5A) and are enwrapped by glia-cell processes (Fig. 6C). Two giant neurons are present in the posterior lateral part of the brain neuropil and are associated with a cluster of enlarged neurons (Fig. 5D). 

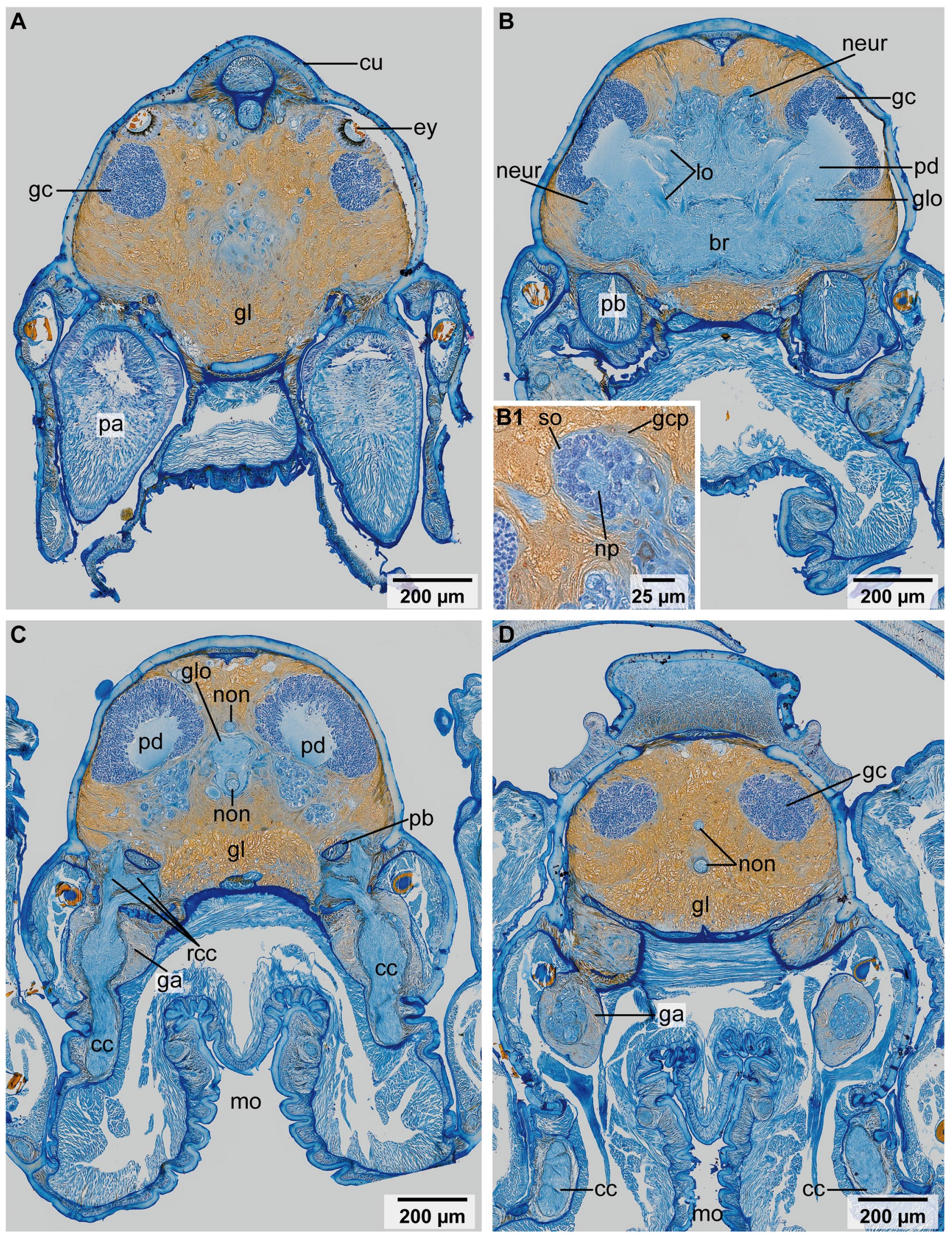
4Fig. 3 Azan staining, $5 \mu \mathrm{m}$, cross sections, frontal to caudal. A Brain is enclosed by a massive layer of glia cells ( $g l$ ) (bright orange). The calyx of the mushroom body is composed of thousands of small neuronal somata called globuli-cells $(g c)$. $c u$ cuticle; ey eye; $p a$ palp. B Neuropil of the pedunculus $(p d)$ of the mushroom body appears as a smooth mass, while in the neuropil of the brain $(b r)$ neurites are discernible. Extensions of the pedunculus, so called lobes (lo), connect the mushroom bodies with each other. Neurons (neur) of the brain are enlarged compared to those of the mushroom bodies $(\mathrm{gc})$. glo glomerular neuropil; $p b$ base of palp. B1 Somata ( $s o$ ) of the small mushroom bodies are enlarged and surrounded by glia cell processes $(g c p)$. $n p$ neuropil. C Nuchal organ nerves (non) are clearly discernible between the dorsally located homogenous glomerular neuropil ( $g l o$ ) of the mushroom bodies. The three roots ( $r c c)$ of the circumesophageal connectives $(c c)$ surround the base of the palp $(p b)$ and merge in a ganglion $(g a) . g l$ glia cell layer; mo mouth; $p d$ pedunculus. D Nuchal organ nerves (non) run through the layer of glia cells $(g l)$ and connect the sensory cells of the nuchal organ (no) to the brain. $g c$ globuli cells; $g a$ ganglion

\section{Fine structure of mushroom bodies}

In Azan and silver staining the neuropil of the mushroom body appears as a homogeneous, dense mass without any clearly differentiated neurites (Figs. 3B, C, 4A-C, $5 \mathrm{~A}-\mathrm{C})$. This is in contrast to the neuropil of the brain, where individual neurites can be differentiated in Azan and Palmgren's silver staining (Figs. 3B, 4A-C, 5A, B). The homogeneous appearance is caused by densely packed neurites with a small diameter and the absence of glia-cell processes enwrapping neurites (Fig. 6A, D, E). Neurites of the remaining nervous system are up to 10 times more prominent in diameter than those of the mushroom bodies and partly grouped by glia cell processes (Fig. 6D). However, occasionally glia-cell processes cross the neuropil of the mushroom body (Figs. 5B, C, 8E). Neurites of the pedunculus of the mushroom bodies are densely interwoven. Towards the calyx the neurites parallelize and are put in order (Fig. 6A). Minute mitochondria are numerous in the neurites of the mushroom bodies (Figs. 6E, 8E).

The somata of the mushroom bodies (globuli-cells) differ from those of the remaining brain neuropil, in having none or only a few processes of glia-cells enwrapping the cell bodies. Nuclei are nearly spherical (Fig. 6A, B). Cell bodies are smaller than those of the neurons of the brain and the cytoplasm is less electron-dense than the cytoplasm of neuronal cell somata and glia cells (Figs. 3, 4A, B, 5A, B, 6A-C).

\section{Small mushroom bodies}

Peculiar structures, which resemble miniaturized mushroom bodies, are present in the median dorsal part of the brain neuropil (Figs. 2C, 3B1, 5B). These so-called small mushroom bodies are superficially similar to the mushroom bodies, they differ from the latter in structure of the neuronal somata and the neurites. The size of the somata is rather heterogenous and some are much larger than those of the mushroom bodies. In this respect, their neuronal structure is similar to that of the remaining brain. In contrast to mushroom bodies glia-cells surround the somata and the neurites (Figs. 4B1, 5B, 6C).

\section{Glomerular neuropil}

At the base of the pedunculus of the mushroom bodies and in the merging point of one of the dorsal lobes of the mushroom bodies, darker spherical structures are visible in Azan and Toluidine-blue staining, but not in Palmgren's silver staining (Figs. 2C, 3B, C, 4A, C, 7A). These structures consist of neurites, which contain a much higher number of electron-dense and lucent core vesicles than the surrounding neurites, indicating regions of synaptic concentrations. Electron-dense synaptic cleft material indicates numerous synaptic connections between the nerve fibers (Fig. 7D). In addition, glia-cell processes that possess a very electron-dense cytoplasm invade the neurites of the glomeruli but not the surrounding neurites. Thus, these regions are discernible from the remaining neuropil (Fig. 7B-D).

\section{Glia-cells}

During our study we found four morphologically different types of glia cells. The first type of glia cells forms the largest portion of glia. It consists of cells that form a massive layer that surrounds the entire brain (Figs. 2C, 3, 4A, B, D, E, 8A, B). These cells possess an irregular outer shape and the cytoplasm stains in orange or bright blue in Azan staining (Figs. 3, 4A, D, E). On an ultrastructural level, the cytoplasm of the glia-cell processes is electron-dense and stains in shades of grey (Fig. 8A, B). They contain a large number of filaments that do not show a special pattern nor do they form bundles. Soma and karyoplasm of these cells are remarkably electrondense and can thus be distinguished from neuronal somata and nuclei (Fig. 8D). A cluster of glia-cell somata is present in the ventro-median part of the brain (Fig. 4A). The nuclei possess an irregular outline (Fig. 8D). Gliosomes (Fig. 8B) and only a few electron-dense mitochondria are present in the cytoplasm of the cells.

The second type of glia-cells is radial glia-like and contains bundles of intermediate filaments. These cross the neuropil of the brain and occasionally the neuropil of the mushroom bodies (Figs. 4B, 5B, 8E). Their intermediate filaments are attached to the cuticle and the basal lamina of the prostomium and serve as an anchor-like structure for the cells of the nervous system and the cells, which secrete the cuticle (Fig. 8F). This apico-basal 


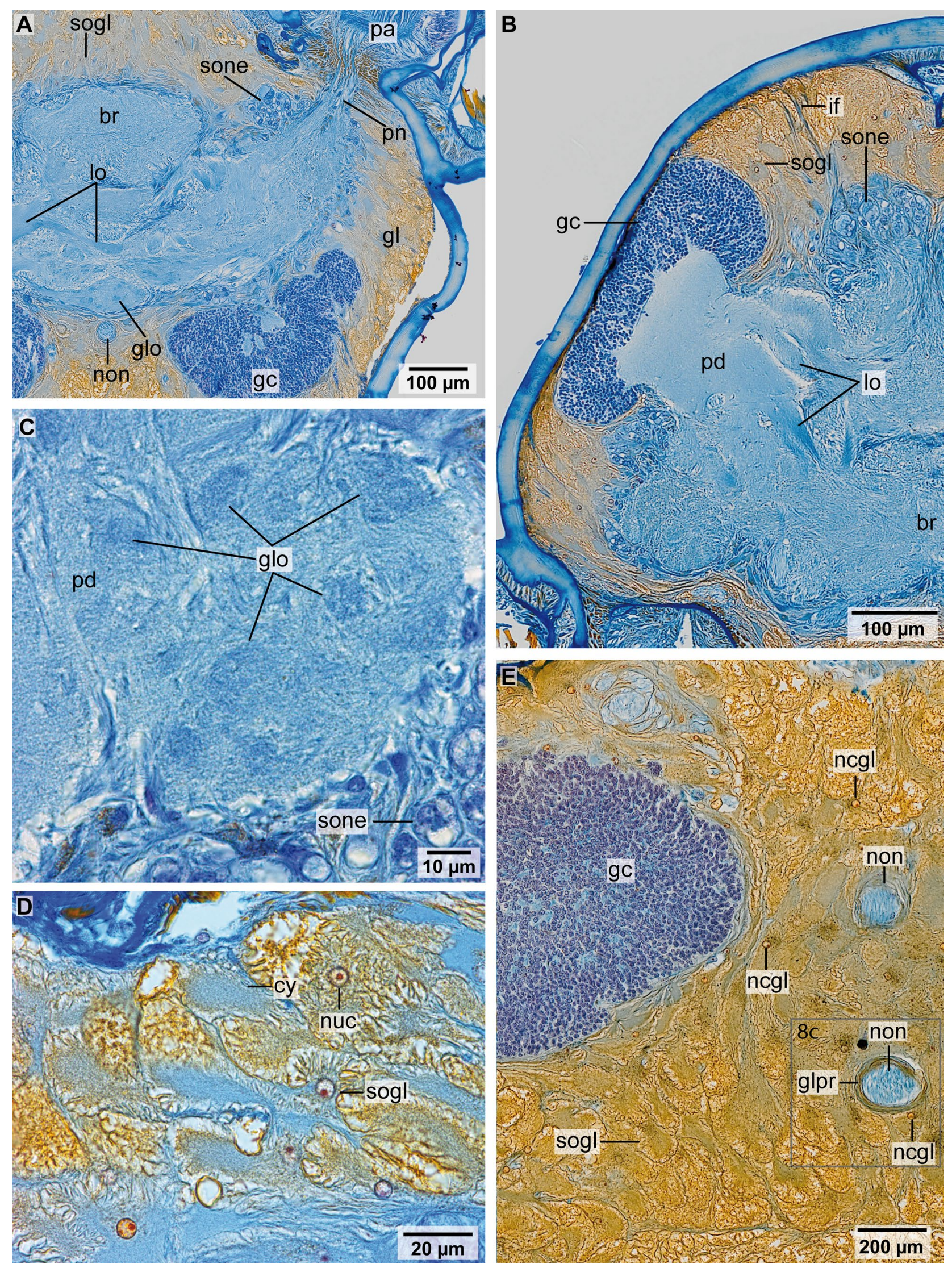


४Fig. 4 Azan staining, $5 \mu \mathrm{m}$. A, C, D, E horizontal sections, B cross section. A Palp nerve ( $p n)$ originates in the region of the glomerular neuropil of the mushroom body. The lobes of the mushroom body (lo ) connect the mushroom bodies on the corresponding side. A third cluster of glomerular neuropil $(\mathrm{glo})$ is present in the median dorsal part of the brain $(b r)$. Somata of the neurons (sone) are clustered along the neuropil of the brain $(b r)$. Somata of glia cells $(\mathrm{sogl})$ are cluster in the ventral median part of the brain $(b r) . g c$ globuli- cells; $g l$ glia layer; non nuchal organ nerve. B Somata of the glia cells ( $\operatorname{sogl}$ ) which surround the whole brain are scattered within the glia cell layer. Glia cells which contain intermediate filaments (if) cross the brain neuropil $(b r)$. The somata of the neurons of the brain (sone) are spherical shaped and enlarged compared to the globuli cells $(g c)$ of the mushroom body. lo lobe of mushroom body; $p d$ pedunculus. $\mathbf{C}$ Glomerular neuropil ( $g l o$ ) is located at the base of the pedunculus $(p d)$ and visible by dark spherical structures in Azan staining. sone somata of the neurons of the brain. D Cytoplasm (cy) of the glia cells which surround the brain is blueish and yellowish in Azan staining. The outer membranes of the somata of the glia cells ( $\operatorname{sog} l$ ) which surround the whole brain, are fringed. nuc nucleus. $\mathbf{E}$ Whole brain is surrounded by a massive layer of glia cells $(g l)$. The nuchal organ nerves (non) are embedded in this layer and are sharply demarcated by processes of glia cells ( $g l p r)$. $g c$ globuli cells; $n c g l$ nucleus of glia cell; $s o g l$ somata of glia cell

polarity as well as the bundles of intermediate filaments characterize these glia cells as radial glia.

A third type of glia-cells separates somata or neurites or groups of somata or neurites from each other. These cells enwrap, e.g., the neurites of the nuchal organ nerves and isolate them from the surrounding nervous tissue (Fig. 8C). These glia-cell send processes between the membranes of the somata; their cytoplasm is very electron-dense (Fig. 8). Somata of these glia-cells are not clustered and are found occasionally (Figs. 6A, C, 8C). Somata and karyoplasm are electron-dense. The cells resemble Schwann cells in the vertebrate nervous system.

The last type of glia-cells is present inside the glomerular neuropil of the brain. This type of glia cell invades regions in the neurites of the mushroom bodies. The cytoplasm is extremely electron-dense and appears in black (Fig. 6C, D). The somata or nuclei of these cells could not be found.

Supportive epidermal cells that secrete the cuticle (epidermal cells) form a layer directly above the type 1 gliacells (Fig. 8F). These epidermal cells lack cilia and possess apical microvilli that extend into the cuticle. Apicall adhaerens junctions followed by septate junctions connect these cells. Bundles of intermediate filaments reinforce the baso-apical axis of these cells and extend into their stalk-like basal section. The basal lamina on which these cells rest is situated at the base of the prostomium (Fig. 2C). Although we expect these supportive epidermal cells to adhere to this basal lamina, we were unable to confirm this due to the enormous size of the brain. However, histological sections show several small and slender cell processes adhering to the basal lamina that we assume to be the expected basal sections of the epidermal cells.

\section{Palp, nuchal organ and eye innervation}

One nerve innervates each palp. Glia cell processes surround neurites or neurite bundles. The palp nerve can be traced from the base of the neuropil of the mushroom body, close to the glomerular neuropil, up to the base of the palp. Here, each palp nerve branches into fine neurites during its course towards the tip of the palps (Figs. 1C, 2, 4A).

Two nerves, a dorsal and a more prominent ventral one connect the sensory cells of the nuchal organ to the brain (Figs. 2B, C, 3C, D, 4D, 8C). Several layers of glia-cell processes enwrap both nerves and isolate the neurites from the surrounding neuropil (Figs. 4D, 8C). The dorsal nuchal organ nerve originates in the commissure connecting the small mushroom bodies (see below) (Figs. 2C, 5B). This nerve can be traced on its way posterior through the neuropil of the brain and beyond (Figs. 3D, 4D). The ventral nuchal organ nerve originates where the lobes of the peduncules meet medially (Fig. 2C). The dorsal and the ventral nuchal organ nerves finally merge and connect to the neurites of the sensory cells of the nuchal organ (Fig. 2B).

Sensory cells of the two pairs of eyes are connected by two optical nerves, which merge in the mid-dorsal glomerular neuropil of the lobes of the mushroom bodies (Figs. 2C, $5 \mathrm{~A}$ ), in the same region where the nuchal organ nerves originate.

\section{Discussion}

\section{General remarks}

The entire brain is intra- or basiepidermal; the basal lamina or extracellular matrix is located at the posterior margin of the prostomium. Thus, the prostomial epidermis is a multilayered or at least pseudostratified neuroepithelium. It contains supportive epidermal cells that show a distinct apicobasal polarity and secretes the cuticle. Different kinds of nerve cells and glia cells are located basal to the epidermal cells, most likely penetrated by their slender nasal sections that adhere them to the basal lamina. Glia cells, neurites and somata of the neuron form a basiepidermal brain. Musculature or body cavities are absent within the brain region. This situation is comparable to the brain of oweniids and magelonids. In these species, the brain is also intraepidermal with a layer of epidermal cells intermingled between the somata of the neurons. Radial glia-cells that contain intermediate filaments are also present. However, a prominent glia-cell layer surrounding the brain is not present (Beckers et al. 2019a, b). Since intraepidermal central nervous systems are 

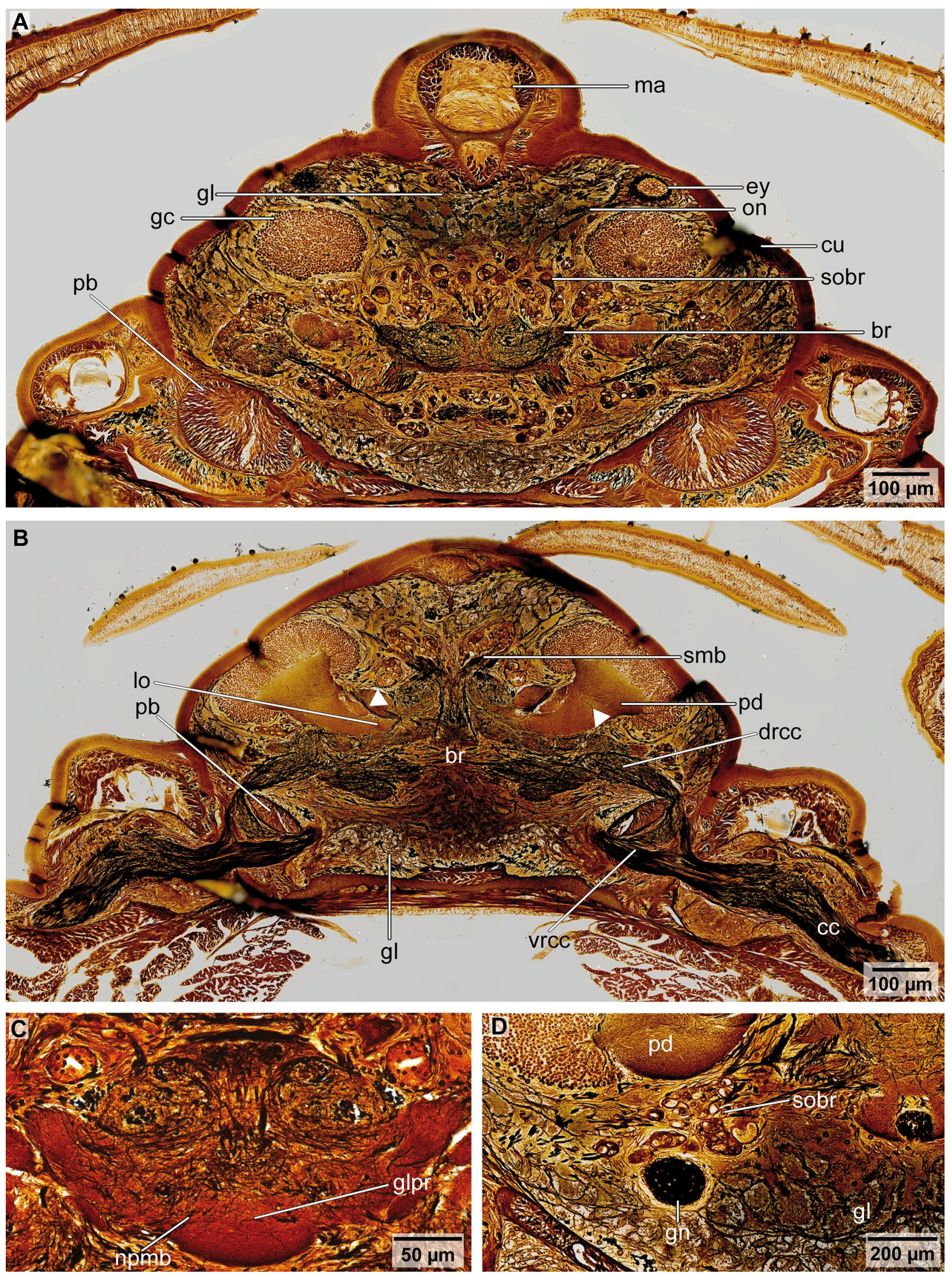
४Fig. 5 Palmgrens silver impregnation, $5 \mu \mathrm{m}$, cross sections, frontal to caudal. A Whole brain neuropil $(b r)$ is surrounded by a massive layer of glia cells $(g l)$. Somata of the mushroom bodies, the globuli cells $(g c)$ are much smaller than the somata of the neurons of the brain (sobr). An optical nerve (on) connects the sensory cells of the eyes (ey). A massive cuticle $(c u)$ surrounds the whole brain. $m a$ median antenna; $p b$ base of palp. B Neuropil of the pedunculus $(p d)$ of the mushroom bodies appears as a smooth mass. Lobes (lo) of the mushroom bodies merge medially. Occasionally glia cell processes (arrowheads) cross the neuropil of the mushroom body. In the neuropil of the brain, $(b r)$ individual neurites are discernible. The circumesophageal connectives $(c c)$ arise from three roots (two visible here) which surround the base of the palp $(p b)$. drcc dorsal root of cc; $g l$ glia layer; $v r c c$ ventral root of cc. $\mathbf{C}$ Homogenous neuropils of the mushroom bodies merge medially. Glia cell processes ( $g l p r)$ cross the neuropil. D Giant neuronal somata $(g n)$ are located ventro-lateral of the brain neuropil between the glia cell layer $(g l)$. sobr somata of the brain; $p d$ pedunculus of mushroom body

a common feature of spiralian taxa (Bullock and Horridge 1965; Schmidt-Rhaesa et al. 2015) the most likely plesiomorphic condition is retained in Sthenelais boa.

\section{Mushroom bodies}

The mushroom bodies in polychaete annelids are also known as corpora peduculata. According to Golding (1992) these structures are restricted to subgroups of the Errantia and to Serpulida. The latter could not be confirmed during our survey across polychaete subgroups (own unpublished data). Though there are several light microscopical and confocal studies (see Hanström 1927, 1928; Heuer et al. 2010), the ultrastructure of annelid mushroom bodies has scarcely been studied (Golding 1992). According to our data, annelid mushroom bodies are paired structures that are located underneath the epidermis and extend into the brain. They consist of a dorso- or dorsolateral cup-shaped multilayer of small somata with little cytoplasm surrounding the small nucleus of each perikaryon. There is not glia enwrapping of the somata nor does glia or matrix separate the entire structure from the remaining brain. The neurites are small in transverse section and all possess the same diameter; they form a strong bundle called pedunculus that projects from the somata ventro-medially into the center of the brain. The merger of the peduncules in the center of the brain may give rise to the ventral nuchal organ nerve. There are no specific glia-cells associated with the mushroom bodies; only occasionally radial glia may pass the peduncula. In this way, shape, structure and composition allows unambiguously identifying annelid mushroom bodies in histological sections.

\section{"Small mushroom bodies"}

The so-called "small mushroom bodies" in, e.g., Ophiodromus obscura (Verill 1873; Hanström 1927) or in
Sthenelais boa illustrate the general problem in identifying mushroom bodies. Although they appear superficially similar in consisting of a head formed by perikarya and a pedunculus composed of neurites, there are striking anatomical differences. In these structures, neurites have larger diameter and glia-cell processes enwrap the somata and neurites, like in the brain. This shows that not all structures that superficially resemble mushroom bodies are mushroom body homologues (in the sense of the upper mentioned characteristics). In addition, this might be a reason why mushroom body-like structures are assumed to be present in many polychaetes taxa (Hanström 1927; Heuer et al. 2010).

\section{Palp innervation}

Palp nerves originate in the glomerular neuropil at the base of the pedunculus (palp glomeruli). The same pattern is found in Hediste (Nereis) diversicolor (Müller 1776) and Harmothoe areolata (Grube 1860) with immunohistochemical methods (Heuer and Loesel 2008, 2009) and Azan staining (own observation) indicating homology. In Oweniidae and Magelonidae (Palaeoannelida), the sister group to the remaining Annelida, palps are innervated by two nerves originating in the brain (Orrhage 1966; Beckers et al. 2019a, b). Since neither a glomerular neuropil nor mushroom bodies are present in these species a statement about whether palps of Palaeoannelida are homologous to the palps of Sthenelais boa is difficult.

Recently the chemosensory function of palps was demonstrated for Platynereis dumerilii (Chartier et al. 2018). Since palp innervation and the overall anatomy of mushroom bodies and glomerular neuropil is comparable in these species, a chemosensory function of palps in $S$. boa can be assumed.

\section{Glomerular neuropil}

The glomerular neuropil in the antennal lobe described for insects resembles to some extent the ones described in polychaetes. The dark coloration of these structures is i.a. caused by glia cell processes, which possess electron-dense cytoplasm and are called intraglomerular glia in insects (Oland and Tolbert 1996). These processes enwrap regions of the neuropil and isolate them from the surrounding neuropil (Edwards and Tolbert 1998). A similar situation is found Sthenelais boa. The gliacells invade but do not sharply enwrap regions of the neuropil of the pedunculus of the mushroom bodies. In insects, synapses of the neuropil are assembled in these glomeruli. In S. boa high abundance of dense and lucent 

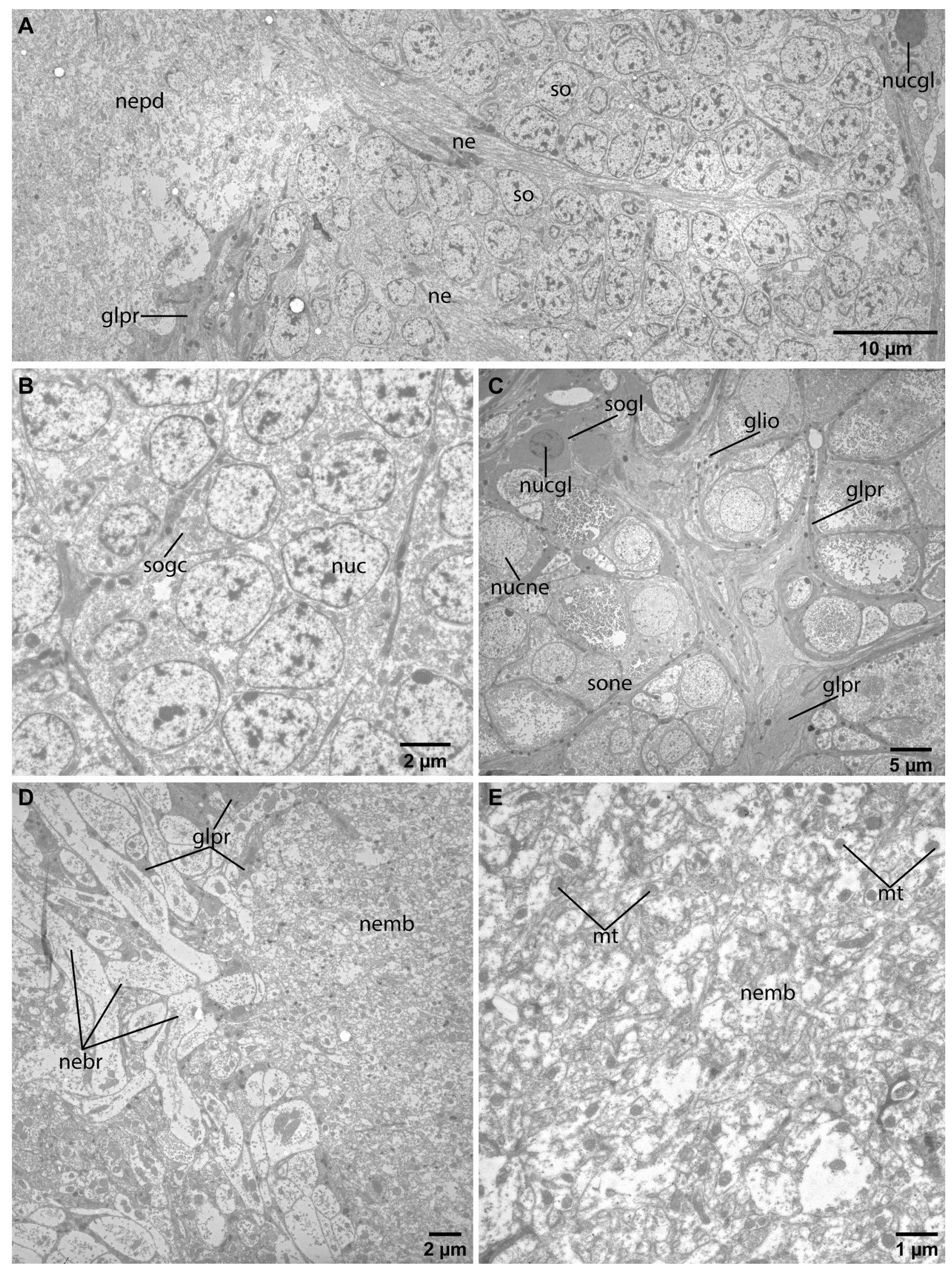
4Fig. 6 Ultrastructure $(70 \mathrm{~nm})$ of mushroom bodies and neuronal somata. A Neurites in the pedunculus of the mushroom bodies (nepd) are densely interwoven, however, in the apical part of the pedunculus, towards the somata of the globuli cells $(\operatorname{sog} c)$ the neurites (ne) parallelize. Glia cell processes ( $g c p r)$ partly separat the somata of the globuli cells $(\operatorname{sog} c)$ from the neuropil of the pedunculus. A glia layer $(g l)$ surround the whole calyx. Nuclei of glia cells (nucgl) are very electron-dense. B Somata of the globuli cells $(\operatorname{sog} c)$ are not enwrapped by glia cell processes. Cytoplasm is less electron-dense that that of the neuronal somata. nuc nucleus of globuli cell. $\mathbf{C}$ Somata of the neurons (sone) are enwrapped by electron-dense glia cell processes ( $g l p r)$. The nucleus of neurons (nисne) is electronlucent. The cytoplasm of glia cells contains gliosoms (glio). The nucleus $(n u c g l)$ and the soma ( $(\mathrm{ogl})$ of the glia cells appear electrondense. D Neurites of the brain (nebr) are much larger in diameter than the neurites of the mushroom bodies (nemb). In addition, glia cell processes ( $g l p r)$ invade the neuropil of the brain. E Neurites of the neuropil of the mushroom bodies (nemb) are of small diameter and densely interwoven. Mitochondria $(m t)$ are numerous

core vesicles in the neurites and the presence of synaptic cleft material, also indicate high synaptic activity.

In Hediste diversicolor and Platynereis dumerilii and other polychaetes the palp- or/and the nuchal organ nerve terminates in the glomerular neuropil (Heuer and Loesel 2008, 2009; Chartier et al. 2018; this study). In Eurythoe complanata (Pallas 1766) (Amphinomida) the glomerular neuropil is associated with the nuchal organ nerve (Marsden and Galloway 1968; Beckers and Tilic 2021), palp nerves are not in contact with this region (if present at all), mushroom bodies are also not present (Beckers and Tilic 2021).

In certain Spiralia-like hoplonemertean species (Nemertea) similar spheroid, in Azan staining, darker structures are found in the posterior part of the brain (Beckers et al. 2018; Beckers and von Döhren 2015). Here, the glomerular neuropil is associated with the cerebral organ nerve, a nerve that connects the sensory cells of this chemical sense organ to the brain (Beckers et al. 2018). Hence, the glomerular neuropil in polychaetes and nemerteans is associated with presumably olfactory sense organs and, thus, with processing of chemical cues, irrespective of which sensory organ the input comes from or if mushroom bodies are present.

However, a final statement on the evolution of a glomerular neuropil is difficult, since most taxa throughout Spiralia do not show a glomerular neuropil despite possessing the same chemical sense organs.

\section{Glia-cells}

A massive layer of glia-cells surrounds the brain of $S$. boa. These cells most likely serve as a protective barrier for the brain. Since those cells have not been found in any other taxon outside Aphroditiformia (own observation) such glia-cells might be exclusive for this taxon.
Other glia-cells whose processes enwrapped neurons and neurites of the brain are present in several taxa of Errantia (Golding 1992). These glia-cell additionally isolate certain nerves, such as the nuchal organ nerve, from the surrounding neuropil. However, these glia-cells are not present in the sister group of the remaining Annelids, Magelonidae and Oweniidae and most likely also not in Chaetopteriformia (Beckers et al. 2019a, b) but in Amphinomida (Beckers and Tilic 2021). Thus, this morphotype of glia-cells most likely evolved in the stem lineage of Amphinomida + Sipuncula and Pleistoannelida.

Radial glia-cells are present throughout Annelida (Beckers et al. 2019a, b; Beckers and Tilic 2021) and Spiralia (Helm et al. 2017) and seem to be a basic feature of the nervous system of Bilateria.

\section{Comparative mushroom body anatomy and evolution}

There are similarities between the anatomy of mushroom bodies in insects and polychaetes. The conspicuous homogeneous structure and dense packing of the peduncle neuropil of the mushroom body in Azan-, Palmgrens silver- or Toloudine-blue staining is caused by the dense organization of the neurites and their small diameter. In contrast to annelids, the neuropil of insect mushroom bodies is surrounded by a glia coating, separating it from the brain neuropil (Mancini and Frontali 1967). That is not the case in S. boa. In addition, somata of globulicells in polychaetes or somata of Kenyon-cells in insects do not possess glia processes enwrapping, which is in contrast to the somata of the neurons of the remaining nervous system (Bullock and Horridge 1965; Tolbert and Hildebrand 1981).

Mushroom bodies are well studied in arthropods and especially in insects. Presently no phylogenetic tree provides evidence that mushroom bodies could be homologous. Since neurons are subjected to fundamental functional constrains (Faisal and Neishabouri 2017), such as noise reduction, metabolic costs and conduction speed versus neurite diameter an independent evolution of these higher brain centers is not unlikely. These strong functional constrains a nervous system is subjected to give rise to ask whether mushroom bodies are probably a structural representation of a specific neuronal function, comparable to a specific hardware in a computer that is needed to run a certain program. If so, one would expect to find a correlation between a specific life style or a specific sensory input or sense organs and mushroom bodies.

In insects mushroom bodies serve as centers for memory and learning, indicating that animals possessing such structures are capable to show a more elaborated 


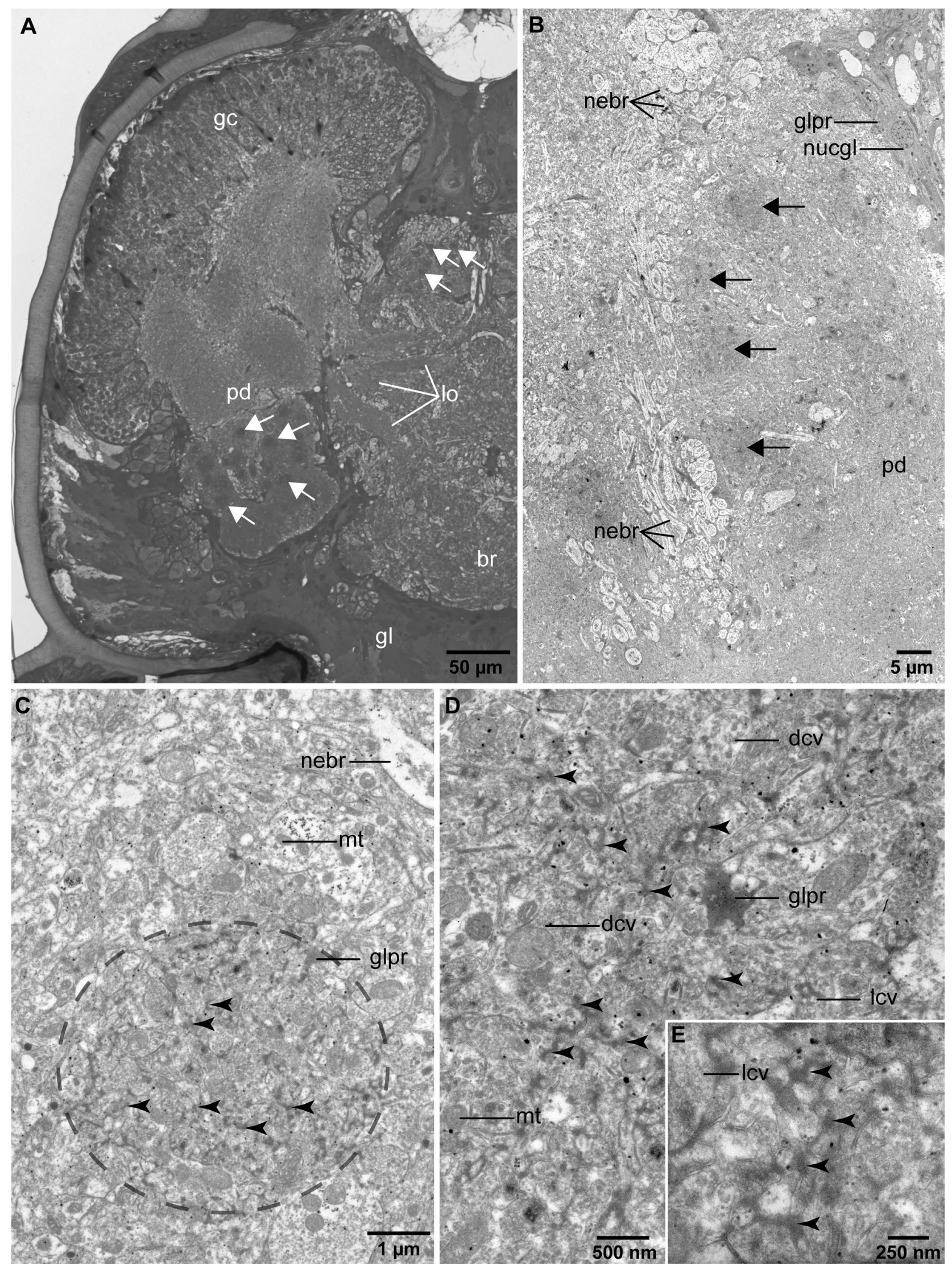


4Fig.7 A Toluidine-blue, semi-thin Sects. $(1 \mu \mathrm{m})$, only left half of brain shown. B, C, D Ultrastructure $(70 \mathrm{~nm})$. A Three cluster of glomerular neuropils (arrows) are present (two shown), two at the base of the pedunculus $(p d)$ of the mushroom bodies and one in the dorsomedian part of the brain $(b r)$. Lobes $(l b)$ of mushroom bodies connect both mushroom bodies medially. $g c$ globuli cells; $g l$ glia cell layer. B Neurites of the brain (nebr) are more prominent compared to the neurites of the pedunculus $(p d)$ of the mushroom body. Glia cell processes $(g l p r)$ partly separate the neuropil of the pedunculus $(p d)$ from the neuropil of the brain. arrows glomerular neuropil; nucgl nucleus glia cell. C Higher magnification of $(\mathbf{B})$ the region of the glomerulum (dashed circle) is discernible from the remaining neuropil of the pedunculus, since it contains more electron-dense glia cell processes ( $g l p r)$ and a high abundance of synaptic cleft material (arrowheads). $m t$ mitochondria; nebr neurites of the brain. D Cytoplasm of the glia cell processes ( $g l p r)$ is almost black. Much more dense- $(d c v)$ and few more lucent- $(l c v)$ core vesicles are present in the neurites of the glomeruli than in the surrounding neuropil. The synaptic cleft material (arrowheads) is located inside the synaptic cleft, is electron-dense and contributes to the darker coloration of the glomerular neuropil. $m t$ mitochondria. E High abundance of the synaptic cleft material (arrowheads) is an indicator for high number of synaptic connections in the glomerulum. $l c v$ lucent core vesicles

behavior than those species which do not possess mushroom bodies (Strausfeld et al. 1995; Ganeshina and Menzel 2001). The same recently turned out to be the case in malacostacan crustaceans (Maza et al. 2021). Since sigalionid polychaetes are active hunters the explanation given for higher brain centers in insects may also apply to this group. Mushroom bodies, however, are only found in a small subset of vagile, actively foraging polychaete species of the monophyletic Errantia (Heuer et al. 2010; Loesel and Heuer 2010; unpl. P. Beckers), but not all species of the Errantia possess mushroom bodies, even though some of them are active hunters, such as amphinomids-, eunicid- or glycerid species (Hanström 1927; Heuer et al. 2010; Beckers and Tilic 2021). This contradicts at least a strict correlation between predatory life style and the presence of mushroom bodies,

Nemerteans are also active and mobile hunters among lophotrochozoans but do not possess mushroom body-like structures visible in Azan staining or TEMstudies (Beckers and von Döhren 2015; Beckers et al. 2018). Lineus viridis (Müller 1774) seems to be the only nemertean species, in which a mushroom body-like function was assumed for the neuropil connecting the cerebral sense organ to the dorsal brain lobe. Evidence for this assumption was provided by staining with an antibody directed against a mushroom body specific protein (DC0) in a Drosophila species (Wolff and Strausfeld 2015). This, however, is basically no evidence for a homology but rather indicates that specific neurons are involved in processing a certain kind of neuronal response. Recent studies on nemerteans actually show that these are only subcompartments, which have nothing in common with mushroom bodies themselves (Gasiorowski et al. 2021).

This missing correlation between predation or hunting and higher brain functions such as learning and memory on the one hand and the occurrence of mushroom bodies on the other also occurs in octopuses (Mollusca). These animal do not possess mushroom bodies but show a high degree of behavioral repertoires (Wollesen et al. 2009; Wollesen 2015).

Hanström (1927) already speculated that the evolution of mushroom bodies in Annelida is connected to the tactile and chemosensory performance of palps and nuchal organs. Syllids do also possess well-developed palps innervated in the same manner as in Sthenelais boa and nuchal organs. However, there are no signs of mushroom bodies or glomerular neuropil in the brain (Weidhase et al. 2017).

Recent investigations on the chemosensory responses of Platynereis dumerilii suggest that mushroom bodies are involved in the processing of chemical stimuli, comparable to the situation in insects (Chartier et al. 2018). Tomer et al. (2010) showed that mushroom bodies (or homologous structures in vertebrates (pallium)) in annelids and vertebrates develop from these same molecularly defined subregions. The authors suggest that a precursor of mushroom bodies was already present in the last common ancestor of Bilateria. If this was true, our initial question for the specific structure 

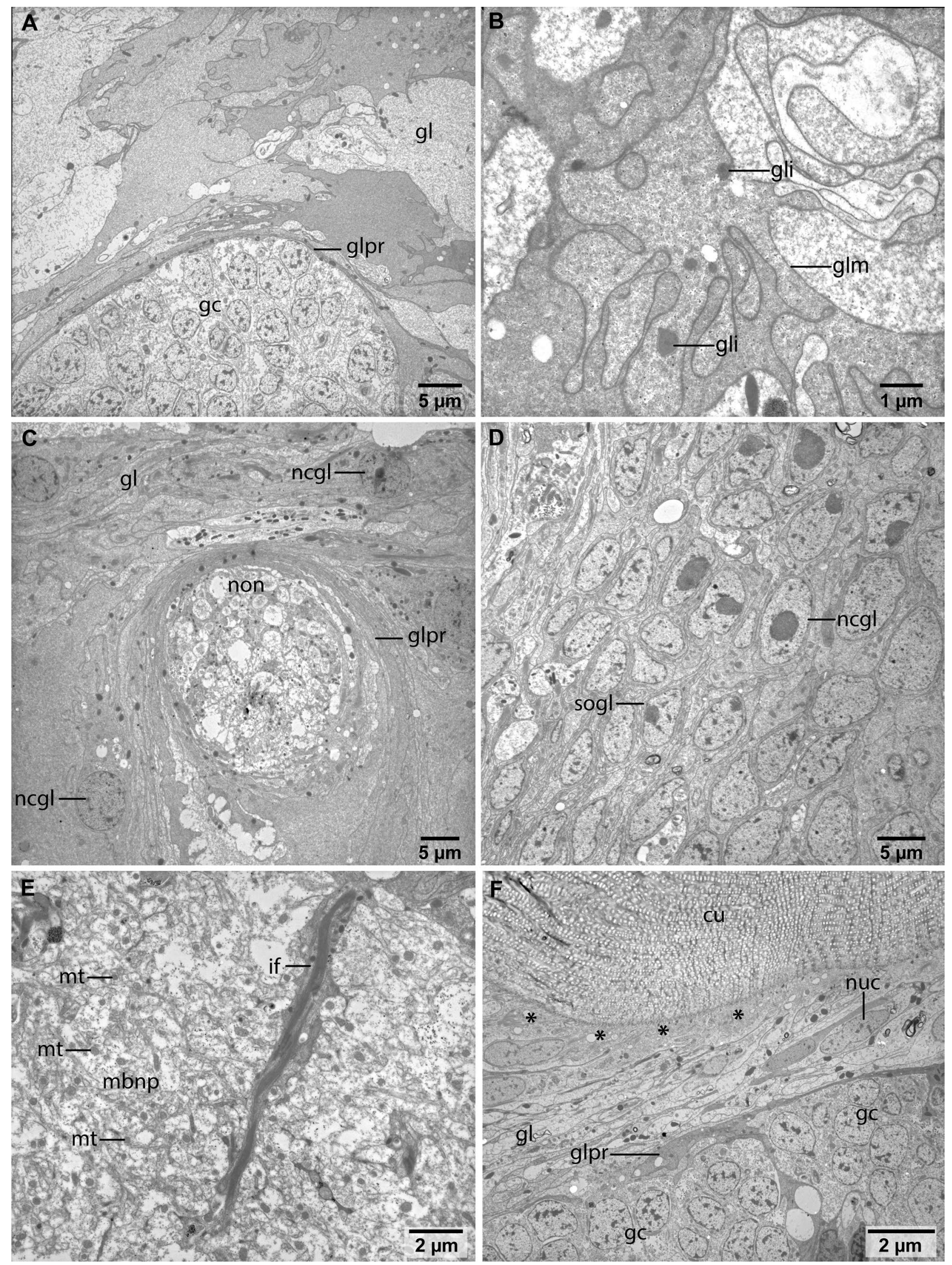
4Fig. 8 Ultrastructure $(70 \mathrm{~nm})$ of glia cells. A Prominent glia layer $(g l)$ surrounds the whole brain. Small glia cell processes ( $g l p r)$ separate the globuli cells $(g c)$ from the glia layer. B Glia cell membranes are highly fringed and interlocked. Gliosomes ( $g l i)$ are present. C Neurites of the nuchal organ nerve (non) are arranged in parallel to the body axis. Several layers of glia cell processes ( $g l p r)$ enwrap the nerve. $g l$ glia layer; $n c g l$ nucleus of glia cell. D Cluster of somata of glia cells $(\operatorname{sog} l)$. Somata as well as nuclei $(n c g l)$ are electron-dense. $\mathbf{E}$ Radial glia cells which contain prominent intermediate filaments (if) occasionally cross the neuropil of pedunculus of the mushroom body (mbnp). Neurites of the mushroom body contain numerous small mitochondria $(m t)$. F Epidermal cell layer (asterisk) which secretes the cuticle $(c u)$ is situated above the glia cell layer $(g l) . g c$ globuli cells; glpr glia cell processes

and composition of the mushroom bodies is still not solved. This unsolved problem, however, calls for further comparative studies and may foster finding correlations between the presence of mushroom bodies and the behavior, sensory structures and life style in annelids, correlations that could generate testable hypotheses on the function of mushroom bodies in polychaete annelids.

Acknowledgements We appreciate the help of Christiane Wallnisch and Tatjana Bartz for laboratory assistance. We thank Abigail Miller for proofreading the manuscript. We acknowledge the help of the staff of the Station de Biologie Marine in Concarneau (France) for providing lab facilities.

Author contributions PB conceived the study. CP and PB gathered the data. All authors analyzed the data, wrote and discussed the manuscript. All authors read and approved the final manuscript.

Funding Open Access funding enabled and organized by Projekt DEAL. The $\mu \mathrm{CT}$-scanner used for this investigation was funded by the Deutsche Forschungsgemeinschaft (INST 217/849-1 FUGG).

Availability of data and materials The voucher material of Sthenelais boa is deposited at the Institute of Evolutionary Biology and Ecology of the University of Bonn. All aligned serial sections, as well as $\mu \mathrm{Ct}$-scans are freely available in MorphDbase: www.morphdbase.de. $\mu$ CT part1: www.morphdbase.de/?P_Beckers_20200310-M-115.1. $\mu$ CT part2: www.morphdbase.de/?P_Beckers_20200310-M-114.1. Azan, cross-sections: www.morphdbase.de/?P_Beckers_20200310-M-108.1. Azan, horizontal sections: www.morphdbase.de/?P_Beckers_20200 310-M-110.1. Palmgrens silver, cross: www.morphdbase.de/?P_Becke rs_20200310-M-109.1

Code availability Not applicable.

\section{Declarations}

Conflict of interest The authors declare that they have no competing interests.

Ethics approval Not applicable.

Consent to participate Not applicable.

Consent for publication Not applicable.
Open Access This article is licensed under a Creative Commons Attribution 4.0 International License, which permits use, sharing, adaptation, distribution and reproduction in any medium or format, as long as you give appropriate credit to the original author(s) and the source, provide a link to the Creative Commons licence, and indicate if changes were made. The images or other third party material in this article are included in the article's Creative Commons licence, unless indicated otherwise in a credit line to the material. If material is not included in the article's Creative Commons licence and your intended use is not permitted by statutory regulation or exceeds the permitted use, you will need to obtain permission directly from the copyright holder. To view a copy of this licence, visit http://creativecommons.org/licenses/by/4.0/.

\section{References}

Ax P (2000) Multicellular animals II. Springer Verlag, Berlin

Baskin D (1971a) Fine structure, functional organization and supportive role of neuroglia in Nereis. Tissue Cell 3:579-588

Baskin D (1971b) The fine structure of neuroglia in the central nervous system of nereid polychaetes. Z Zellforsch Mikrosk Anat 119:295-308

Beckers P, Tilic E (2021) Fine structure of the brain in Amphinomida (Annelida). Acta Zool 1-13. https://doi.org/10.1111/azo.12383

Beckers P, von Döhren J (2015) Nemertea (Nemertini). In: Schmidt-Rhaesa A, Harzsch S, Purschke G (eds) Structure and evolution of invertebrate nervous systems. Oxford University Press, Oxford, pp 148-165

Beckers P, Krämer D, Bartolomaeus T (2018) The nervous systems of Hoplonemertea (Nemertea). Zoomorphology 137:473-500

Beckers P, Helm C, Bartolomaeus T (2019a) The anatomy and development of the nervous system in Magelonidae (Annelida) —insights into the evolution of the annelid brain. BMC Evol Biol 19:1-21

Beckers P, Helm C, Purschke G, Worsaae K, Hutchings P, Bartolomaeus $\mathrm{T}$ (2019b) The central nervous system of Oweniidae (Annelida) and its implications for the structure of the ancestral annelid brain. Front Zool 16:6. https://doi.org/10.1186/s12983-019-0305-1

Beckers P, Müller C, Wallnisch C, Bartolomaeus T (2021) Getting two birds with one stone: combining immunohistochemistry and Azan staining in animal morphology. J Biol Methods 8:1-7. https://doi.org/ 10.14440/jbm.2021.354

Bullock T, Horridge G (1965) Structure and function in the nervous systems of invertebrates. Freeman and Company, San Francisco

Cardona A, Saalfeld S, Schindelin J, Arganda-Carreras I, Preibisch S, Longair M, Tomancak P, Hartenstein V, Douglas RJ (2012) TrakEM2 software for neural circuit reconstruction. PLoS ONE 7(6):e38011. https://doi.org/10.1371/journal.pone.0038011

Chartier T, Deschamps J, Duerichen W, Jekely G, Arendt D (2018) Wholehead recording of chemosensory activity in the marine annelid Platynereis dumerilii. R Soc Open Biol 8(10):180139. https://doi.org/10. 1098/rsob.18139

Dujardin F (1850) Mémoire sur le système nerveux des insectes. Ann La Sci Nat Zool 14:195-206

Edwards J, Tolbert L (1998) Insect neuroglia. In: Harrison F, Locke M (eds) Microscopic anatomy of invertebrates. Wiley-Liss, New York, pp 449-466

Faisal A, Neishabouri A (2017) Fundamental constraints on the evolution of neurons. In: Shepherd S (ed) The Wiley Handbook of evolutionary neuroscience. Wiley Blackwell, New York, pp 153-172

Ganeshina O, Menzel R (2001) GABA-Immunoreactive neurons in the mushroom bodies of the Honeybee: an electron microscopic study. $\mathrm{J}$ Comp Neurol 437:335-349

Gasiorowski L, Boerve A, Cherneva IA, Orus-Alcalde A, Hejnol A (2021) Gene expression in the developing nemertean brain indicates convergent evolution of complex brains in Spiralia. bioRxiv. https://doi.org/ 10.1101/2021.03.29.437382 
Golding D (1992) Annelida, nervous system. In: Harrison F, Gardiner S (eds) Microscopic anatomy of invertebrates. Wiley-Liss, New York, pp 153-179

Grobe P, Voigt L (2008) MorphDBase-A morphological description database. J Morphol 269:1478-1479

Grobe P, Voigt L (2014) Documenting morphology: Morph D Base. In: Waegele JW, Bartolomaeus T (eds) Deep Metazoan phylogeny: the backbone of the tree of life. Berlin, DeGruyter, pp 475-503

Haller B (1889) Beiträge zur Kenntnis der Textur des Central-Nervensystems höherer Würmer. In: Arbeiten aus dem zoologischen Institut der Universität Wien und der zoologischen Station in Triest, vol 8, pp 175-312

Hamaker JJ (1898) The nervous system of Nereis virens Sars: a study in comparative neurology. Bull Mus Comp Zool 32:89-124

Hanström B (1927) Das zentrale und periphere Nervensystem des Kopflappens einiger Polychäten. Zeitschrift Für Morph Ökol Tiere 7:543-596

Hanström B (1928) Vergleichende Anatomie des Nervensystems der wirbellosen Tiere unter Berücksichtigung seiner Funktion. Springer, Berlin

Helm C, Karl A, Beckers P, Kaul-Strehlow S, Ulbricht E, Kourtesis I, Kuhrt H, Hausen H, Bartoloameus T, Reichenbach A, Bleidorn C (2017) Early evolution of radial glia cells in Bilateria. Proc R Soc B 284:20170743

Helm C, Beckers P, Bartolomaeus T, Drukewitz S, Kourtesis I, Weigert A, Purschke G, Worsaae K, Struck TH, Bleidiorn C (2018) Convergent evolution of the ladder-like ventral nerve cord in Annelida. Front Zool 15:36. https://doi.org/10.1186/s12983-018-0280-y

Heuer C, Loesel R (2008) Immunofluorescence analysis of the internal brain anatomy of Nereis diversicolor (Polychaeta, Annelida). Cell Tissue Res 331:713-724. https://doi.org/10.1007/ s00441-007-0535-y

Heuer C, Loesel R (2009) Three-dimensional reconstruction of mushroom body neuropils in the polychaete species Nereis diversicolor and Harmothoe areolata (Phyllodocida, Annelida). Zoomorphology 128:219-226. doi: 10.1007/s00435-008-0063-7

Heuer C, Müller C, Todt C, Loesel R (2010) Comparative neuroanatomy suggests repeated reduction of neuroarchitectural complexity in Annelida. Front Zool 7:13

Kremer J, Mastronarde D, McIntosh J (1996) Computer visualization of three-dimensional image data using IMOD. J Struct Biol 116:71-76. https://doi.org/10.1006/jsbi.1996.0013

Landolt AM (1965) Elektronenmikroskopische Untersuchungen an der Perikaryenschicht der Corpora pedunculata der Waldameise (Formica lugubris) Mit besonderer Berücksichtigung der NeuronGlia-Beziehung. Z Zellforsch Mikrosk Anat 66:701-736

Landolt A, Ris H (1966) Electron microscope studies on soma-somatic interneuronal junctions in the corpus pedunculatum of the wood ant (Formica lugubris). J Cell Biol 28:391-403

Loesel R, Heuer C (2010) The mushroom bodies-prominent brain centres of arthropods and annelids with enigmatic evolutionary origin. Acta Zool 91:29-34

Mancini G, Frontali N (1967) Fine structure of the mushroom body neuropile of the brain of the roach, Periplaneta americana. Cell Tissue Res 83:334-343

Marsden J, Galloway M (1968) The microanatomy of the supra-oesophageal ganglion of Eurythoe complanata (Polychaeta Amphinomidae). Can J Zool 46:349-367

Maza FJ, Sztarker J, Cozzarin ME, Lepore MG, Delorenzi A (2021) A crabs' high-order brain center resolved as a mushroom body-like structure. J Comp Neurol 529:501-523

Oland L, Tolbert L (1996) Multiple factors shape development of olfactory glomeruli: Insights from an insect model system. J Neurobiol 30:92-109
Orrhage L (1966) Über die Anatomie des zentralen Nervensystemes der sedentären Polychaeten. Ark för Zool 19:99-133

Palmgren A (1948) A rapid method for selective silver staining of nerve fibres and nerve endings in mounted paraffin sections. Acta Zool 29:377-392

Purschke G (2005) Sense organs in polychaetes (Annelida). Hydrobiologia 535:53-78. https://doi.org/10.1007/s10750-004-4358-5

Purschke G (2015) Annelida: Basal groups and Pleistoannelida. In: Schmidt-Rhaesa A, Harzsch S, Purschke G (eds) Structure and evolution of Invertebrate nervous systems. Oxford University Press, Oxford, pp 254-312

Radojcic T, Pentreath V (1979) Invertebrate glia. Prog Neurobiol 12:115-179. https://doi.org/10.1016/0301-0082(79)90002-9

Schindelin J, Arganda-Carreras I, Frise E, Kaynig V, Longair M, Pietzsch T, Preibisch S, Rueden C, Saalfeld S, Schmid B, Tinevez J-Y, White DJ, Hartenstein V, Eliceiri K, Tomancak P, Cardona A (2012) Fiji: an open-source platform for biological-image analysis. Nat Methods 9:676-682. https://doi.org/10.1038/nmeth.2019

Schmidt-Rhaesa A, Harzsch S, Purschke G (2015) Structure and evolution of invertebrate nervous systems. Oxford University Press, Oxford

Strausfeld N, Buschbeck E, Gomez R (1995) The arthropod mushroom body: Its functional roles, evolutionary enigmas and mistaken identities. In: The nervous systems of invertebrates: an evolutionary and comparative approach. pp 349-381

Strausfeld N, Hansen L, Li Y, Gomez R, Ito K (1998) Evolution, Discovery, and Interpretations of Arthropod mushroom bodies. Learn Mem 5:11-37. https://doi.org/10.1101/lm.5.1.11

Strausfeld N, Sinakevitch I, Brown S, Farris S (2009) Ground plan of the insect mushroom body: functional and evolutionary implications. J Comp Neurol 513:265-291

Tolbert L, Hildebrand J (1981) Organization and synaptic ultrastructure of glomeruli in the antennal lobes of the moth Manduca sexta: a study using thin sections and freeze-fracture. Proc R Soc Lond B 213:279-301

Tomer R, Denes A, Tessmar-Raible K, Arendt D (2010) Profiling by image registration reveals common origin of Annelid mushroom bodies and vertebrate Pallium. Cell 142:800-809. https://doi.org/ 10.1016/j.cell.2010.07.043

Trujillo-Cenóz O, Melamed J (1962) Electron microscope observations on the calyces of the insect brain. J Ultrasructure Res 7:389-398

Turner C (1899) Notes on the mushroom bodies of the Invertebrates: a preliminary paper on the comparative study of the Arthropod and Annelid Brain. Zool Bull 4:155-160

Weidhase M, Beckers P, Bleidorn C, Aguado M (2017) Nervous system regeneration in Typosyllis antoni (Annelida: Syllidae). Zool Anzeiger 269:57-67. https://doi.org/10.1016/j.jcz.2017.07.004

Wolff G, Strausfeld N (2015) Genealogical correspondence of mushroom bodies across Invertebrate Phyla. Curr Biol 25:38-44. https://doi.org/10.1016/j.cub.2014.10.049

Wollesen T (2015) Mollusca: Cephalopoda. In: Schmidt-Rhaesa A, Harzsch S, Purschke G (eds) Structure and evolution of Invertebrate nervous systems. Oxford University Press, Oxford, pp 222-240

Wollesen T, Loesel R, Wanninger A (2009) Pygmy squids and giant brains: Mapping the complex cephalopod cns by phalloidin staining of vibratome sections and whole-mount preparations. J Neurosci Methods 179:63-67. https://doi.org/10.1016/j.jneumeth. 2009.01.021

Publisher's Note Springer Nature remains neutral with regard to jurisdictional claims in published maps and institutional affiliations. 